International Journal of Social Science and Economic Research

ISSN: $2455-8834$

Volume: 05, Issue: 03 "March 2020"

\title{
A JOURNEY FROM SOCIALISM TO TOTAL REVOLUTION: AN EVALUATIVE STUDY OF LOKNAYAK JAYPRAKASH NARAYAN
}

\author{
Paritosh Barman
}

\begin{abstract}
Assistant Professor, Department of Political Science, Cooch Behar Panchanan
Barma University, Cooch Behar, West Bengal - 736101, India
\end{abstract}

DOI: 10.46609/IJSSER.2020.v05i03.016 URL: https://doi.org/10.46609/IJSSER.2020.v05i03.016

\begin{abstract}
Loknayak Jayprakash Narayan popularly known as JP was a freedom fighter, political reformer and active political leader throughout his life. Jayprakash was educated at universities in the United States, where he became a Marxist Devotee. Upon his return to India, he joined the Indian National Congress. In the Post-Independence period, he left the party to work relentlessly the creation of an Anti-Congress Platform in 1948. By forming the Praja Socialist Party, J.P. gave voice to the marginalized and offered an alternative political platform in 1952 . He tried his best to implement the Sarvodaya Movement, founded by Acharaya Vinoba Bhave.

Jayprakash was an active worker of the Sarvodaya Movement started by Gandhiji and spearheaded by Vinobha Bhave. JP's Sarvodaya meant a new order to set up a classless and stateless society for the people's socialism in the fifties. He was deeply disturbed by the growth of political corruption in India. He was first "JeevanDanee"(devoted life) to Jeevandan Movement led by Vinoba Bhave. To eradicate the dominant party politics he proposed the concept of partyless democracy and communitarian democracy to develop democratic values and culture. Sampurna Kranti or total revolution was the last intellectual contribution of Jayprakash in his unending quest to seek and set up such a socio-economic and political order in the country which would turn India into a democratic, participatory, prosperous nation in the world. This study will focus on social, political contributions of JP to re-construct the Indian society by his unending movements up to death. He devoted himself to purify the political, socio-economic and moral aspects of the people.
\end{abstract}

Keywords: Marxism, Socialism, Sarvodaya, Jeevandan, Total Revolution.

INTRODUCTION 
International Journal of Social Science and Economic Research

ISSN: $2455-8834$

Volume: 05, Issue: 03 "March 2020"

Jay Prakash (JP) Narayan remains one of the most devoted leaders in India. As a nation maker, JP never fixed him with any 'ism' or ideology and never compromised with the prosperity of the country. The meaning of his name 'JP' is 'Victory to the light'. He was born at Sitabdiyara village in Bihar on $11^{\text {th }}$ October 1902. JP was educated at universities of the USA, where he became a Marxist Devotee by his heart. On returning from the USA, he joined Indian National Congress on the call of Nehru to free the country from the grasp of the British Rule. Besides Gandhi, JP was deeply influenced by Bal Gangadhar Tilak, who called Indians to act fearlessly following the ideals of The Geeta. He formed his mind to lead a simple life and work for the nation impressed by the Non-violent Movements of Gandhi. At the early age of 18, he got married to Prabhavati Devi. The marriage proved to be an advantageous one for him, through Father-in-law, who was a national leader, he came into contact with important political leaders. He was jailed many times during the freedom struggle period. He had been the foremost leader and spokesman of Indian Socialism and worked as a socialist leader from 1930 to 1954. He fought up to his last breath to establish a truly equal society with the ideals of social and economic justice in Democratic India. His two major motto of life were liberty and equality for all.

\section{METHODOLOGY}

This research study is based on secondary data mostly on the books and articles related to Jayprakash Narayan. JP's writings are an important source for this study. An attempt has been done to evaluate his thought about the reformation of the Indian political system. After understanding his thought and works, we will realize the role of JP to modify the political system to reconstruct Indian democracy.

\section{OBJECTIVES OF THE STUDY}

a) To understand JP's view on the concept of the Sarvodaya Movement.

b) To know about JP's concept of socialism.

c) To understand JP's role to remake the nation.

d) To understand the relevance of the total revolution based on non-violence for the nationbuilding in India.

\section{JP's role as a revolutionary:}

At the end of his higher study in the USA JP return to India and joined the Indian National Congress to fight against the British Government in 1929. From here onwards, JP played an active role in Indian Freedom Struggle up to Indian Independence achievement. He was jailed in 1932 for actively participating in the Civil Disobedience Movement led by Gandhiji against 


\section{International Journal of Social Science and Economic Research}

ISSN: $2455-8834$

Volume: 05, Issue: 03 "March 2020"

oppressive British Rule. He came in contact with the leaders like Ashok Mehta, Minu Mashani, Ram Manohar Lohia, C. K. Narayan Swami, and others during imprisonment in Nasik Jail in 1932. This contact impressed JP to join the Congress Socialist Party (CSP). ${ }^{1}$ As General Secretary of CSP, he called the Nation to take benefit of World War II to stop British Rule and they are exploitation. He was imprisoned for $9^{\text {th }}$ months again. After his release, he tried his best to bring a compromise between Gandhiji and Subhas Chandra Bose on the question of movement policy but could not succeed in that. ${ }^{2}$

He was arrested by the British Government accused of participating in the Quit India Movement of August 1942. He was changed of the ongoing stir with others and was put in Hazaribagh Central Jail. He escaped from jail on a Diwali day in November 1942 when a large number of guards in Jail were on leave. ${ }^{3}$ This daring escape by JP made him a folk hero.

During the freedom struggle period, JP actively worked as an underground freedom fighter. To stop the terrible exploitation by the British Government he formed and 'Azad Dasta' (Freedom Brigade) in Nepal. After some months he was arrested repeatedly from Punjab while he was traveling by train in September 1943. He was roughly tortured by British Police for taking Freedom Struggle Information. When Gandhi insisted that he would begin negotiations with the British Government only after the unconditional release of Ram Manohar Lohia and JP in April 1946. He was a born fighter against any corruption, injustice, and exploitation of the poor section of the society. So he played an important role to bring a socio-economic change to create a truly equal society for all with justice up to his death. ${ }^{4}$

\section{The role of $\mathrm{JP}$ in the Indian Socialist Movement:}

For nearly 24 years JP worked as socialist from 1930 to 1954 . Gandhiji accepted him to be the greatest authority on Socialism in India. He took many active activities to popularize the Congress Socialist Party and its program. He convinced that without socialism, inequalities, corruption, and exploitation cannot be stopped. The foundation of the Congress Socialist Party (CSP) in May 1934 was an important step in the progress of the Socialist movement in India. The blueprints of CSP were chalked out in Nasik Jail where JP, Ashoke Mehata, Minoo Masani, Lohia were jailed together. Gradually by the time, JP played a role as the most active leader of the Congress Socialist Party and re-organized personality in the field of Indian Socialism. ${ }^{5}$

JP gave very important to the economic problems of the country and the necessity as early as possible with socialistic ideals. According to him 'the root cause of inequalities of wealth lies in the fact that the gifts of nature which yield wealth to men and the instruments of productions have come to be privately owned by people for their benefit. This lead to economic exploitation". 6 JP said that inequalities arose because the means of production were owned by a 


\section{International Journal of Social Science and Economic Research}

ISSN: $2455-8834$

Volume: 05, Issue: 03 "March 2020"

few and that led to the concentration of wealth and exploitation of others. It was because he supported the abolition of private wealth and private ownership. JP wanted the bank, industry, transport, and trade to be nationalized as public property for all. ${ }^{7}$

He emphasized the fact that the state must satisfy the basic need of the people to create a truly democratic, socialistic state with the principle of justice, equality, and liberty. Democracy cannot be successful without the establishment of socialism in the Indian polity. JP was deeply aware of the defects of representative, parliamentary democracy. He stated that socialism is only the way of sharing equally the benefit of state wealth for all.

As a socialist worker, JP had great sympathy for the peasants who badly suffering in many ways in the contemporary situation. He tried to bring a radical change of society in such a way that the suffering of the peasants in the villages could be reduced. He wanted the village to be selfsufficient and radical changes in laws relating to land. He suggested cooperative firms. ${ }^{8} \mathrm{JP}$ followed - the Gandhian method of non-violence and Satyagraha, to implement socialism in the Indian Political environment. He did not advocate Marxist ways of class struggle for his socialistic struggle. JP's concept of Socialism was in his words, "I would like to define a socialist society as one in which the individual is prepared voluntarily to subordinate his interest to the larger interest of the society. The keyword is this definition is "Voluntarily"."'

In his book 'Why Socialism' (1936), JP laid profound importance on economic equality and suggested the abolition of private property as a way of dealing with equality. He blamed private property to the root cause of inequality. In his picture of socialism, JP understood other methods to deal with the problem of inequality such as in equal opportunity for self-development, not equitable apportionment of national wealth and social, educational and services between all. As a Marxist follower, he wanted the abolition of private property to be the only solution to the problem of inequalities. But as a democratic socialist, JP realized that equality has social and political dimensions as well; it needed different policies to cope with them.

\section{JP's role in the Sarvodaya Movement:}

In the Post- Independence Era of India, JP quitted himself from active politics and so-called power politics. Jayaprakash completely broke away with Marxism and turned to Sarvodaya philosophy. He attempted to reinterpret the basic question of individual behavior that he was to exhibit in the realm of politics from an ethical viewpoint. In 1954, he announced at the annual Sarvodaya conference in Bodhgaya, that he would devote all his time and energy to succeed Sarvodaya movements and its principles. He became the first 'Jeevandanee' on the reason for the rise of all. 


\section{International Journal of Social Science and Economic Research}

ISSN: $2455-8834$

Volume: 05, Issue: 03 "March 2020"

He joined the Bhoodan movement led by Acharya Vinobha Bhave to reconstruct the socioeconomic condition in India. He began to establish socialistic principles and ideals through his social activities. JP suggested the replacement of People's Socialism for state socialism. Sarvodaya rejected Rajniti or power politics to set up Lok Satta or Lokniti. Sarvodaya movement stood for a party less democracy which wanted to curve the power centric party politics. Through Sarvodaya programs, JP wanted community-centric panchayats through a participatory way of the people. As a Sarvoday activist, the people have to work in the spirit of co-operation and to support the happiness and elevation of all. ${ }^{10}$ Sarvodaya does not support this view that diverse social interests gave rise to different parties. This movement took the techniques of Ahimsa, truth, and Satyagraha rejecting Marxist violent action. By rejecting power politics, JP wanted an ideal social system which was not a heaven for corrupted politicians, bureaucrats and capitalist, but there was to be self-government, self-management, co-operation, equality, freedom, and brotherhood in the society. ${ }^{11}$

For an ideal and morally successful life, the discipline of physical needs is essential for the good growth of human personality. The socialist way of life is a path of sharing good things through common effort. A problem arises in the country unless members of society learn to keep their wants under control, willing sharing may be difficult to implement in society. According to JP, the remedy will be that every member of the social practices self-discipline and values of socialism. Sarvodaya was a way of implementation of socialist values in the society through voluntarily sharing and cooperative mentality for others. ${ }^{12}$ Since 1953 , JP was deeply thinking about Sarvodaya ideas which might be helpful to achieve socialistic principles.

\section{JP's concept of Partyless Democracy, Communitarian democracy:}

In his pamphlet in 1961, 'Swaraj for the people' he expressed his view on the party less democracy by the direct participation of the people in the governance of the state. He said the Indian People followed western democracy where the government is based on the consent of the people without any participation in the decision-making process of the government. He wanted the participation by the people in the political system and governance to resist the arbitrary action of the decision-makers. According to JP, only participatory democracy could give the people a stake in the democracy as well as a feeling of Swaraj. Some specific conditions were determined by JP for the communitarian democracy following.

a) Education for all, b) Party's spirit should be discarded, c) Real devolution of power and responsibilities to the Panchayats, d) Giving financial autonomy to the institutions and making civil servants accountable. ${ }^{13}$ 


\section{International Journal of Social Science and Economic Research}

ISSN: $2455-8834$

Volume: 05, Issue: 03 "March 2020"

JP was deeply worried about the working of parliamentary democracy in India and criticized the role of the political parties to save their interest only. Political parties are only busy with their majority on vote accounts to win the elections. For the gaining ruling power of the country, parties followed corrupted practices also. JP's concept of participatory democracy was derived from the excellence of the political and economic institutions of ancient India. The goal of this democracy was so designed as to execute the Sarvodaya ideal, which came from ancient Indian philosophy and religion. ${ }^{14}$

\section{JP's concept of Total Revolution:}

The revolutionary concept of total revolution by JP was launched in the wake of the Bihar movement in Patna on June 5 in 1974, popularly known as the JP movement. In a public meeting at Gandhi Maidan, he declared the revolution was not only for students including the resignation of ministers and the dissolution of assembly in Bihar. It was also to solve urgent problems of the nation and a new Usher to set up an ideal socialist structure with democratic values to eliminate economic exploitation and social evils.

The concept of total revolution by JP was one of his most important targets to set up a socialistic culture in India for the people. The primary reason behind this revolution was an active reaction to the contemporary corrupted socio-economic and political situation of the country. The total revolution was a combination of seven revolutions-such as social, political, economic, cultural, educational, ideological and spiritual to bring a permanent change in the Indian society. ${ }^{15} \mathrm{JP}$ launched this innovative concept of revolution with two major objectives - Firstly one is to bring a radical change in every sphere of society through non-violence means and public awareness. The second is JP wanted to challenge the random misuse of power by a single ruling party. He felt a crisis need to raise voice against corruption and abuse of freedom and socio-economic justice of the people.

There were many important features of JP's concept of total revolution to bring a change in the system and mentality of the people together. The first feature was about the method of revolution based on non-violence and truth. He told Gandhiji that there was no need for violent means to change society in India. ${ }^{16}$ The second feature of the total revolution was the revolution would aim to sustain democratic structure for the nation. Thirdly, JP for his revolution was a change in the internal life of an individual as well as the social structure of the society. Fourthly, the total revolution and it would continue to keep on changing our individual and social lives. He stated 'Total revolution was always going on and on ........this knows no respite, no halt and certainly not a complete halt..... ${ }^{17}$ Fifthly, he gave the duty of the leadership of the revolution to the students. To him, students were better at leadership as they have no hunger for power and day to day struggle for survival. Sixthly class struggle is not mean to gain equal power. Another feature 


\section{International Journal of Social Science and Economic Research}

ISSN: $2455-8834$

Volume: 05, Issue: 03 "March 2020"

of total revolution is JP wanted to establish a new political system based on mutual respect, trust and co-operation for all. Bimal Prasad has shown that JP's concept of total revolution was a synthesis of Marxist and Gandhian concept of idealistic humanism with the principles of Western Democracy. ${ }^{18}$

The main cause of JP's attachment to socialism as socialism based on equality and social justice. But the demand for social justice had to be joined to the need for the moral development of individuals. Only material progress cannot lead to social and economic justice. ${ }^{19}$ His total revolution aimed at the new attitude and new system to bring a progressive change to the socioeconomic structure of the country. To create a truly equal society the aim of the total revolution was Sarvodaya and the means of Total Revolution. Therefore we can say that the total revolution was re-shaping of the Sarvodaya movement to implement democratic values in the Indian Society.

Many critics have strongly criticized his concept of Total Revolution as Utopian and impractical. Thinkers like N.G Gorey doubts whether Total Revolution is feasible in a country like India where the fatalism is so deep-rooted. While other people like W.S Kane says that realizing Indian condition, Total Revolution was a long-term target. It may be flexible to take initiatives to win it. JP, himself was aware of the gaps in the revolution. ${ }^{20}$ After MK Gandhi, JP continued the tradition of the politician-saint alive and inspired the new generations with new urge and determination to go forward. He was a fearless and risk-taker person to establish liberty, equality, and justice for all in the country. With humility, towards the end of his life, he stated; "And this unsuccessful life will be blessed a hundred times, it makes the thorny path a bit easier". ${ }^{21}$

\section{Total Revolution and India's Second Freedom:}

JP's exceptional role in Indian politics was to turn student movement into a continuous Total Revolution to meet the challenges against the development of the country. JP was deeply concerned with the existing troubles of poverty, hunger, illiteracy, and inefficiency of the bureaucracy. JP gave an interview that he would like to drastically change the system. As a result, he practiced the innovative ideas of the Total Revolution to reconstruct the nation after Independence. There was a common word about the Emergency period by Mrs. Gandhi that "India's first freedom achieved on the mid-night of 14/15th,1947, ended on the mid-night of 25/26th, 1975." An authoritarian ruler and her government took some arbitrary steps against the voice of the people who were victims of corruption, unemployment, endemic inflation and injustice or oppression. 


\section{International Journal of Social Science and Economic Research}

Volume: 05, Issue: 03 "March 2020"

The results of the JP movement created a huge turmoil in Indian politics and challenges for the ruling government to continue their regime. At midnight on 25 June 1975, President, Fakruddin Ali Ahamedon the advice of Prime Minister signed a proclamation that would come into the effect on the next morning. The President declared a state of Internal Emergency that the security of India was threatened by internal disturbances. ${ }^{22}$ As a result of the declaration, JP and hundreds of prominent leaders of the Opposition were arrested to stop the wave of Total Revolution on 26th June 1975. JP pressed the resignation of the Prime Minister, Mrs. Indira Gandhi by calling of total revolution against authoritarian rule. The normal political procedures were suspended; the basic federal provisions of the Constitution and guaranteed under Article 19 were suspended. This Emergency created a dark period in the Indian political process. Mrs. Gandhi had been complaining that Opposition and its disrupting politics had been opposing her activities to move the country forward economically. ${ }^{23}$ She made a lot of complaints to denounce the Oppositions and their efforts. But a self-appointed dictator could not run the empire more as the voice on the truth line. JP had won with India regaining its freedom in March 1977 by destroying Congress dominion. In Patna, JP declared at a massive rally, “...after 27 years of freedom, people of this country is wracked by hunger, rising prices, corruption.... Oppressed by every kind of injustice..... it's a Total Revolution we want, nothing less...." Indeed, Total Revolution was a strategy of direct action to bring about a radical change in the social system. It was considered to be a continuous movement. According to JP, the Total Revolution would be able to purify the socio-economic, political and ethical life of the country and to eliminate rampant corruption.

\section{CONCLUSION}

JP worked as a socialist from 1932 to 1954. He had been the foremost leader and spokesman of Indian socialism. He used the concept of socialism blending with Gandhian Socialism for the Indian perspective. He gradually changed his political ideas to adjust to the necessity of the Indian polity. His theory of Democratic Socialism was different from Western Political Thinkers. He became the torchbearer of Gandhiji's ideas of peace, non-violence and Gram Swaraj. JP strongly talked against the serious defects of parliamentary democracy in India. He tried his best to establish communitarian democracy which was more and more decentralized so that people can take part more and more in the administration for their development.

With the help of a communitarian democratic system, JP attempted to reconstruct the nation by the elimination of power centric party politics in the Government. He recognized the maladies of power centric party activities seriously to destroy people's rights. JP thought that the total revolution is permanent. It will keep on changing both the personal and social lives of the Indian Polity. JP explained how the total revolution would bring positive changes against all types of 


\section{International Journal of Social Science and Economic Research}

ISSN: $2455-8834$

Volume: 05, Issue: 03 "March 2020"

corruption. In the Post-Independence Phase, his political ideas brought a moral fabric, peoplecentric political culture and a ray of hope to make people-centric democratic government. His Non-Congress Leadership after independence was a dedicated service for the country to reconstruct the nation with real democratic values and attitudes to save the interest of the people.

After the independence of India, JP was only 'Crusader' to launch a total revolution in the country without any interest in power. He called total revolution as a permanent revolution to be continued to bring a change not only in the mentality of the people but also in the socioeconomic system of the country. ${ }^{24}$ JP's total revolution aimed to achieve basic changes in the social, cultural, political and economic values of the Indian people. He used the term 'total' in the sense of a comprehensive revolution affecting all aspects of social life. ${ }^{25}$

JP's most enduring contribution to Indian politics was the JP movement, he led to oppose Mrs. Gandhi, Which provoked Emergency. The first Non-Congress Party to run the Central Government by Janata Party, he can take credit to bring a change against congress domination in Post-Independence India. According to JP, total revolution no respite, no halt, not a complete halt. JP wrote several books and articles on the reconstruction of the Indian Polity. He awarded Magsaysay award for public service in 1965 and was posthumously awarded "Bharat Ratna" in 1999 for the contribution of social and political leadership in India.JP never wanted any power, position, and fame for himself. This selfless leader was dedicated to making an ideal India with the establishment of equality, freedom, and justice for all. Indeed, his political ideas emphasized the need for moral development, non-violence and participatory democracy to reconstruct the nation.

\section{REFERENCES}

1. K. N. Pathak, JP: A Rebel always, Press Information Bureau, Govt. of India, August-15, 2014.

2. K. N. Pathak, JP: A Rebel always, Press Information Bureau, Govt. of India, August-15, 2014.

3. Mahajan, V.D, Modern Indian Political Thought, S. Chand and Company (Pvt. Ltd), New Delhi, 1998.

4. Gandhi, A.K, Biography of Loknayak JP, Ocean Books Pvt. Ltd, New Delhi, 2016, p.37.

5. Varma, VP, Modern Indian Political Thought, Laxmi Narayan Agarwal publisher, 1998, p.597.

6. Narayan, JP, Why Socialism, All India Congress Socialist Party, Published by Janamandal Press, Banaras, p.70.

7. Gandhi, A.K, Biography of Loknayak JP, Ocean Books Pvt. Ltd, New Delhi, 2016, p.101. 
International Journal of Social Science and Economic Research

ISSN: $2455-8834$

Volume: 05, Issue: 03 "March 2020"

8. Mahajan, V.D., Modern Indian Political Thought, S. Chand \& Co. (Pvt. Ltd.), New Delhi, 1998, P.346.

9. Jagadish P. Sharma and Mirian Sharma,(1982). The Sarvodaya Movement and Social Change, Firma KLM Pvt. Ltd., 1982, p.208.

10. Mahajan V.D, Modern Indian Political Thought, S. Chand and Co. Pvt. Ltd), New Delhi, 1998.

11. Gupta, Nitish Das, The Social and Political Theory of Jayprakash Narayan, South Asian Publishers Pvt. Ltd., New Delhi, 1997, p.77.

12. Prasad, Bimal. (ed). JP Narayan, Essential Writings (1929-1979), Konark Pub. Pvt. Ltd, 2002.p185.

13. Sarat Mishra, JP Narayan and his contribution to a social movement in India, RJHSS, Vol.-III, 2012.

14. Dasgupta, Nitish, The Social and Political Theory of JP Narayan, South Asian Publisher, New Delhi, 1997.

15. JP Narayan, "My concept of Total Revolution" in Sandip Das, ed. op.ct. p.48.

16. JP Narayan, "My concept of Total Revolution" in Sandip Das, ed. op.ct. p.57.

17. 17. Bimal Prasad, ed., "A revolutionary quest" Selected writings of JP Narayan, (New Delhi: Oxford University Press 1998) p.369.

18. Bimal Prasad, JP's concept of Total Revolution in Das, ed. op cit. p.280.

19. Sandip Das, Towards a RE-evaluation of Loknayak, in Das, ed. p.370.

20. Sebasti, L.Raj, Total Revolution, The final phase of JP Narayan's political philosophy (Madras: Satya Nilam Publication, 1986) pp.196-198.

21. Sinha Nilima, "JP in remembering our leaders, (new Delhi: Children Book Trust, 1990) p.174.

22. Sharad Mishra, Sharad, JP Narayan and his contribution to Social Movement in India, RJHSS, Volume-3,2012.

23. 2THEPOINT, News Paper report, October 12, 2017.

24. Prasad, Bimal, GANDHI, NEHRU AND JP, studies in Leadership and Legacy, PROMILLA\& CO. PUBLISHERS, 1985, p.319.

25. Brahmanand, (ed), Towards Total Revolution, Bombay Popular Prakashan, 1978,p.97. 